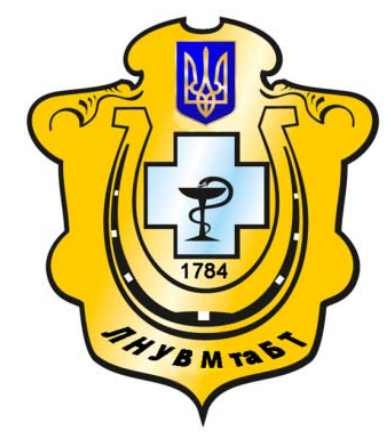

Науковий вісник Львівського національного університету ветеринарної медицини та біотехнологій імені С.З. Гжицького

Scientific Messenger of Lviv National University of Veterinary Medicine and Biotechnologies named after S.Z. Gzhytskyj

doi:10.15421/nvlvet7614

ISSN 2519-2701 print

ISSN 2518-1327 online

$\underline{\text { http://nvlvet.com.ua/ }}$

\title{
Ринкові можливості та загрози молокопереробних підприсмств України
}

\author{
H.C. Косар ${ }^{1}$, Н.P. Кубрак ${ }^{2}$ \\ nata_kosar@ukr.net,nadiyakubrak@gmail.com \\ ${ }^{1}$ Львівський національний університет «Львівська політехніка» \\ вул. Степана Бандери, 12, Львів, 79013, Украӥна, \\ ${ }^{2}$ Львівський національний університет ветеринарної медицини та біотехнологій імені С. 3. Гжицького, \\ вул. Пекарська, 50, м. Львів, 79010, Украӥна
}

\begin{abstract}
У сучасних умовах молокопереробні підприємства зіткнулися з великою кількістю загроз для подальшої своєї діяльності. Вони пов'язані насамперед зі скороченням величини попиту на їхню продукиію на зовнішньому ринку через призупинення експортних поставок продукиії у Росію, зменшенням доходів населення України і відповідно величини внутрішнього попиту, низькою якістю вітчизняної сировини, зменшенням ї̈ обсягів та зростанням цін на неї, збільшенням обсягів закупівлі молокопродуктів у приватних та фермерських господарствах населення. Проте останнім часом з'явилися $і$ нові ринкові можливості для молокопереробних підприємств, які обумовлені зростанням в Украӥні обсягів поставок молока екстра татунку як сировини для подальшого виробництва, збільщенням попиту на молочні продукти з боку країн Близького Сходу та Північної Африки, Китаю, щьо вимагає дослідження споживчих уподобань на відповідних ринках. Для утримання існуючої та збільшення частки ринку України молокопереробні підприємства повинні приділяти увагу заходам паблісіті та стимулювання збуту для пропагування споживання саме продуктів промислового виробництва.

Ключові слова: можливості молокопереробних підприємств, загрози молокопереробних підприємств, домашні та фермерські господарства, експорт молокопродуктів, імпорт молокопродуктів, просування молокопродуктів на ринку.
\end{abstract}

\section{Рыночные возможности и угрозы молокоперерабатывающих предприятий Украины}

\author{
H.C. Косар ${ }^{1}$, Н.P. Кубрак ${ }^{2}$ \\ nata_kosar@ukr.net, nadiyakubrak@gmail.com \\ ${ }^{1}$ Львовский национальный университет «Львовская политехника», \\ ул. Степана Бандеры, 12, Львов, 79013, Украина; \\ ${ }^{2}$ Львовский нацииональный университет ветеринарной медицины и биотехнологий имени С.3. Гжицкого, \\ ул. Пекарская, 50, г. Львов, 79010, Украина
}

\begin{abstract}
В современных условиях молокоперерабатывающие предприятия столкнулись с большим количеством угроз для дальнейшей своей деятельности. Они связаны прежде всего с сокращением величины спроса на их продукиию на внешнем рынке из-за приостановки экспортных поставок продукции в Россию, уменьшением доходов населения Украины и соответственно величины внутреннего спроса, низким качеством отечественного сырья, уменьшением его объемов и ростом иен на него, увеличением объемов закупки молокопродуктов в частных и фермерских хозяйствах населения. Однако в последнее время появились и новые рыночные возможности для молокоперерабатывающии предприятий, которые обусловлены ростом в Украине объемов поставок молока экстра сорта в качестве сырья для дальнейшего производства, увеличением спроса на молочные продукты в страны Ближнего Востока и Северной Африки, Китая, что требует исследования потребительских предпочтений на соответствующих рынках. Для удержания существующей и увеличение доли рынка Украины молокоперерабатывающие предприятия должны уделять внимание мерам паблисити и стимулирования сбыта для пропаганды потребления именно продуктов промышленного производства.
\end{abstract}

Citation:

Kosar, N., Kubrak, N. (2017). Market opportunities and threats milk processing enterprises Ukraine. Scientific Messenger LNUVMBT named after S.Z. Gzhytskyj, 19(76), 72-76. 
Ключевые слова: возможности молокоперерабатывающих предприятий, угрозы молокоперерабатывающих предприятий, домашние и фермерские хозяйства, экспорт молокопродуктов, импорт молокопродуктов, продвижение молокопродуктов на рынке.

\title{
Market opportunities and threats milk processing enterprises Ukraine
}

\author{
N. $\operatorname{Kosar}^{1}$, N. Kubrak ${ }^{2}$ \\ nata_kosar@ukr.net, nadiyakubrak@gmail.com \\ ${ }^{1}$ Lviv National Polytechnic University «Lviv Polytechnic», \\ Stepan Bandera Str., 12, Lviv 79013, Ukraine; \\ ${ }^{2}$ Lviv national university of veterinary medicine and biotechnologies named after S. Gzhytskyj, \\ Pekarska Str., 50, Lviv, 79010, Ukraine
}

\begin{abstract}
The reducing of population incomes of Ukraine, the increase of prices for products of industrial production caused by increasing of demand for milk and other dairy products, which offer home enterprises and farms on the market. This negatively affects on the magnitude of demand for the products of dairy enterprises, which should enhance their communication activities with an emphasis on the quality of the offered products on the market and their compliance with existing standards, adherence of proper sanitary and hygienic conditions in their production, constantly carry out research customer needs, offering them new products and looking for new markets. The purpose of this study is to analyse the opportunities and threats of the manufacturers on the market of milk and dairy products of Ukraine, determine perspective directions of activization of their marketing activities. Lately the functioning of dairy enterprises accompanied by the existence of significant threats for their activities. The significant reduction of manufacturing in Ukraine caused by a significant reduction in the supply of the products in Russia, by the crisis in the global dairy market, by a decrease in the volume of domestic raw materials and its low quality. As a result of decrease in the profitability of production in recent years, dairy enterprises are experiencing a deficit of financial resources. In 2017 compared to 2016 in Ukraine forecasted decrease of milk production due to the dwindling number of cows in all kinds of farms and increase the value of its imports. The increase in sales of products dairy enterprises can be due to the increase in supplies of products for export. Significant prospects for growth in the export of dairy products are for Ukrainian producers to the markets of the countries of the Middle East and North Africa, but it requires the appropriate adaptation of commodity assortment of dairy enterprises through the study of consumer preferences in their respective markets. To retain the existing and increasing the share of the Ukrainian market great attention of dairy enterprises should pay on publicity and sales promotion, combining their actions within the framework of the implementation of the main measures. It is about promoting the consumption of just products of industrial production through their tasting in educational institutions, organization of excursions for schoolchildren and students on dairy enterprises with explaining the benefits of their products compared with «bazarnoû", conduct independent assessment of the quality of such products and similar private farms with the spread of the results in the press, on radio and television, in the Internet.

Key words: opportunities of dairy enterprises, threats of dairy enterprises, home enterprises and farms, exports of dairy products, imports of dairy products, the promotion of dairy products on the market.
\end{abstract}

\section{Вступ}

Скорочення доходів населення України, зростання цін на продукцію промислового виробництва обумовили зростання попиту на молоко та молокопродукти, які пропонують домашні та фермерські господарства на ринку. Це негативно позначається на величині попиту на продукцію молокопереробних підприємств, які повинні активізувати свою комунікаційну діяльність 3 акцентом на якість пропонованих на ринку товарів та їхню відповідність наявним стандартам, дотримання належних санітарно-гігієнічних умов при їх виробництві, постійно проводити дослідження потреб клієнтів, пропонуючи їм нові товари та шукати нові ринки збуту.

Особливості маркетингової діяльності молокопереробних підприємств достатньо широко досліджені у науковій літературі. Зокрема, у (Kubrak et al., 2013) визначено напрями підвищення конкурентоспроможності молокопереробних підприємств шляхом використання окремих маркетингових інструментів. У (Petrynyak, 2011) подано напрями удосконалення організаційного та інформаційного забезпечення маркетингової діяльності молокопереробних підприємств, їх асортиментної та збутової політики. У (Poperechnyy and Kudla, 2016) автори значну увагу приділяють дослідженню інфраструктури аграрного ринку. Проте зміна факторів середовища функціонування вітчизняних молокопереробних підприємств суттєво вплинула на загрози та можливості для їхньої подальшої діяльності, що відповідно визначає і зміну пріоритетів у вдосконаленні окремих складових їх маркетингової діяльності.

Метою даної статті є дослідження можливостей та загроз виробників на ринку молока та молокопродуктів України, визначення перспективних напрямів активізації їхньої маркетингової діяльності. 3 цією метою було поставлено такі завдання:

- дослідити пропозицію на ринку молока і молокопродуктів України та фактори, які визначають ії зміну;

- дослідити попит на ринку молока і молокопродуктів України та фактори, які визначають його зміну;

- проаналізувати особливості експорту та імпорту молока й молокопродуктів українськими виробниками;

- визначити, на яких складових маркетингової діяльності в умовах сьогодення виробники повинні зосередити свої зусилля.

\section{Матеріал і методи досліджень}

Проведене дослідження базується на використанні наукових публікацій вітчизняних та зарубіжних уче- 
них у сфері маркетингу, вторинній маркетинговій інформації про ринок молока та молокопродуктів України. При написанні роботи були використані загальнонаукові методи дослідження - аналізу, синтезу, узагальнення.

\section{Результати та їх обговорення}

Значне зростання вартості паливно-мастильних матеріалів, віддаленість молокозаводів від сировинної бази, нерозвинена структура заготівельних пунктів у сільській місцевості, зростання вартості сировини, знецінення української валюти негативно впливають на розвиток молокопереробних підприємств та призводять до скорочення обсягів їх виробництва. Зокрема у 2016 р. в Україні вироблено 1,6 млн т молокопродуктів, що на 0,3\% менше, ніж у 2015 р. та на 15,79\% менше, ніж у 2014 p. (Moloko ta molokoprodukty..., 2016). Суттєве зменшення обсягів виробництва молокопродуктів в Україні у 2015 р. було обумовлене значним скороченням поставок продукції у Росію та кризою на світовому молочному ринку.

У структурі виробництва молокопродуктів України в 2016 р. найбільша частка припадала на питне молоко $(56,8 \%)$ та йогурти $(25,8 \%)$. При цьому в 2016 р. зросла лише пропозиція кисломолочного сиру (на 3,9\% більше, ніж у 2015 р.) та вершкового масла (на 0,1\%). Відбулося зменшення обсягів виробництва більшості молокопродуктів - майже на 8\% скоротилося виробництво жирних сирів, на 4\% - молока та на 1,4\% - кисломолочної продукції (йогурт, кефір, сметана). Аналізуючи обсяги виробництва молокопродуктів України у 2016 р. порівняно 3 2014 р., варто зазначити, що найбільше падіння спостерігалося 3 таких товарних групах як молоко ($17,08 \%)$, твердий сир $(-13 \%)$, масло $(-11,4 \%)$ та кисломолочна продукція $(-11,16 \%)$.

У таблиці 1 подана інформація про найбільших виробників молочної продукції України за результатами діяльності у 2015 р.

У таблиці 2 визначено основні види продукції та географію їх збуту для найбільших молокопереробних підприємств України за результатами діяльності у 2015 p.

Внаслідок зменшення рентабельності виробництва продукції протягом останніх років молокопереробні підприємства відчувають дефіцит фінансових ресурсів.

Таблищя 1

Інформація про найбільших виробників молокопродуктів України у 2015 р.

\begin{tabular}{|c|c|c|c|}
\hline Рейтинг & Найменування підприємства & Власник & $\begin{array}{l}\text { Дохід у } 2015 \text { р., } \\
\text { млрд грн. }\end{array}$ \\
\hline 1. & «Терра Фуд» & Войтович С. & 3,435 \\
\hline 2. & «Молочний Альянс» & Шпиг Ф., Деркач О. & 3,300 \\
\hline 3. & «Danone Україна» & Danone & 2,100 \\
\hline 4. & «Альміра» & Балюк O. & 1,986 \\
\hline 5. & Група компаній «Комо» & Fromer Holding Limited & 1,780 \\
\hline 6. & «Житомирський маслозавод» — компанія «Рудь» & Рудь П., Вівсик О. & 1,637 \\
\hline 7. & «Люстдорф» & Остапенко Л., Васильєв О. & 1,511 \\
\hline 8. & «Milkiland Україна» & Юркевич А., Юркевич О. & 1,363 \\
\hline 9. & «Вімм-Білль-Данн Україна» & $\begin{array}{l}\text { «Вімм-Білль-Данн продукти } \\
\text { харчування» (РФ) }\end{array}$ & 1,362 \\
\hline 10. & «Волошкове поле» & Табалов А., Табалов О. & 1,304 \\
\hline
\end{tabular}

Складено на основі (TOP-10 naybil'shykh vyrobnykiv molochnoyi produktsiyi v Ukrayini)

Таблиця 2

Характеристика продуктової та збутової політики найбільших молокопереробних підприємств України

\begin{tabular}{|c|c|c|}
\hline Найменування компанії & Основні види продукції & Географія збуту \\
\hline $\begin{array}{l}\text { «Терра Фуд» (19 підприємств } \\
\text { на території України) }\end{array}$ & $\begin{array}{l}\text { Цільномолочна продукція, сир, рослинно- } \\
\text { вершкові суміші, вершкове масло. Лідер - на } \\
\text { ринку фасованого вершкового масла і рослин- } \\
\text { но-вершкових сумішей }\end{array}$ & $\begin{array}{l}\text { Охоплює понад } 40 \text { країн світу, у т. ч. } \\
\text { країни Близького Сходу, Північної } \\
\text { Африки, Балканів, Китай, США і } \\
\text { Північну Корею }\end{array}$ \\
\hline $\begin{array}{l}\text { «Молочний Альянс» (6 підпри- } \\
\text { ємств на території України) }\end{array}$ & $\begin{array}{l}\text { Молоко, сири, цільно- і кисломолочна проду- } \\
\text { кція }\end{array}$ & $\begin{array}{l}\text { Охоплює } 35 \text { країн світу, серед яких } \\
\text { арабсько-мусульманські країни та } \\
\text { Китай }\end{array}$ \\
\hline $\begin{array}{l}\text { «Danone Україна» - підрозділ } \\
\text { французької продовольчої } \\
\text { групи Danone (підприємства у } \\
\text { м. Херсоні та м. Кременчуці) }\end{array}$ & $\begin{array}{l}\text { Йогурти, сирки, продукти дитячого харчуван- } \\
\text { ня. }\end{array}$ & Україна \\
\hline $\begin{array}{l}\text { «Альміра» (7 } \text { підприємств у } \\
\text { Полтавській області) }\end{array}$ & $\begin{array}{l}\text { Сухі молочні продукти, масло, сир, спреди, } \\
\text { молочні консерви. Лідер на ринку сиру і сир- } \\
\text { них продуктів в Україні ( } 23 \% \text { цього ринку), } \\
\text { вершкового масла і рослинно-вершкових } \\
\text { сумішей }(16 \%)\end{array}$ & $\begin{array}{l}\text { Охоплює понад } 50 \text { країн світу, у т.ч. } \\
\text { країни СНД, Африки, Близького } \\
\text { Сходу, США, Мексику, Японію }\end{array}$ \\
\hline 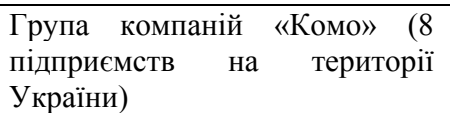 & $\begin{array}{l}\text { Цільномолочна продукція, сир, суха молоч- } \\
\text { на сироватка }\end{array}$ & $\begin{array}{l}\text { Активно експортувала продукцію у } \\
\text { Росію, тепер орієнтується насампе- } \\
\text { ред на ринки Китаю і Казахстану. }\end{array}$ \\
\hline
\end{tabular}

Складено на основі (ТOP-10 naybil'shykh vyrobnykiv molochnoyi produktsiyi v Ukrayini) 
При подальшому збільшенні вартості основної сировини - молока, це може призвести до банкрутства тих молокопереробних підприємств, на яких використовується застаріле обладнання і виробничий процес не $є$ достатньо ефективним.

Негативно на розвиток молокопереробних підприємств впливає і низька якість вітчизняної сировини молока - порівняно з іншими країнами. Необхідно враховувати, що у деяких країнах молоко поділяють на групи не лише за якісними показниками, а й за напрямами використання. Суттєво відрізняється і ціна такого молока. Зокрема, у США виділяють такі чотири його групи (Tsikhanovs'ka, 2016):

- молоко, яке призначене для подальшого споживання як питне і яке має найбільшу ціну закупівлі (перший клас);

- молоко, яке призначене для подальшого виробництва вершків, йогуртів, сметани та іншої подібної продукції (другий клас);

- молоко, яке призначене для подальшого виробництва твердих сирів (третій клас);

- молоко, яке призначене для виробництва масла, сухого молока (четвертий клас), закупівельна ціна на яке $\epsilon$ найнижчою.

Проте у 2016 р. якість молока як сировини для молокопереробних підприємств поліпшилася, що підтверджується даними про зростання частки поступлення молока екстра гатунку з 10,3\% у 2015 р. до 14,6\% у першому кварталі 2017 р., а вищого гатунку - з 35,2\% до $36,7 \%$ та зменшення частки молока першого гатунку за досліджуваний період з 49,6\% до 42\% (Yakist' moloka...). Регіонами виробництва молока екстра гатунку є Вінницька, Полтавська, Київська, Черкаська, Житомирська та Чернігівська області. У 2016 р. надходження молока базової жирності на молокопереробні підприємства зменшилося на 1,6\% порівняно з 2015 р., а загалом закупівля молока у 2016 р. скоро- тилася на 9,3\%. Вирішення проблеми забезпечення молокопереробних підприємств сировиною здійснювалося за рахунок зростання у три рази надходження давальницької та власновиробленої сировини.

У 2017 р. порівняно з 2016 р. в Україні прогнозується зменшення виробництва молока на 2,88\%. Це обумовлене насамперед скороченням у 2016 р. поголів'я корів у всіх видах господарств на 2,7\%. Споживання молока і молокопродуктів населенням у розрахунку на одну особу прогнозується у 2017 р. на рівні 208,5 кг при раціональній нормі - 380 кг. Скорочення власного виробництва молока призведе до збільшення величини його імпорту на $30 \%$, хоча загалом частка імпорту у споживанні населенням України молокопродуктів не перевищуватиме $2 \%$. Основними країнами-імпортерами молока в Україні у 2016 р. були Німеччина (40\% усього обсягу), Бельгія, Франція, Туркменістан. При цьому структура імпорту суттєво змінилася порівняно з 2012 р., коли 80\% молока імпортувалося в Україну з Білорусі та лише 20\% — 3 країн EC.

Збільшення обсягів реалізації продукції молокопереробних підприємств може бути обумовлене зростанням обсягів поставок продукції на експорт. Аналіз вторинної маркетингової інформації свідчить, що у 2016 р. основу експортних поставок молокопереробних підприємств України становило молоко (47\% у загальній величині поставок молокопродуктів), вершки згущені та молочна сироватка (22\%), частка вершкового масла становила $11 \%$, незгущеного молока й вершків - 10\%, сирів - 7\%, ферментованих або сквашених молока та вершків - 3\%. Інформація про поставки українських молокопродуктів на експорт подана у таблиці 3.

Табличяя 3

Інформація про поставки українських молокопродуктів на експорт

\begin{tabular}{|l|l|}
\hline \multicolumn{1}{|c|}{ Найменування товарів } & \multicolumn{1}{c|}{ Основні країни-імпортери } \\
\hline Сухе молоко та вершки & $\begin{array}{l}\text { Казахстан (17\%), Туркменістан (15\%), Бангладеш (8\%), Вірменія (7\%) та Грузія } \\
(5 \%)\end{array}$ \\
\hline Сири & Казахстан (46\%), Молдова (32\%), Сгипет (9\%), Азербайджан (4\%), Грузія (2\%) \\
\hline Вершкове масло та молочні жири & Казахстан (24\%), Грузія (15\%), Сгипет (11\%), Марокко (11\%), Молдова (6\%) \\
\hline
\end{tabular}

Складено на основі (Molochna heohrafiya abo komu nasha «molochka» do smaku)

Значні перспективи зростання експорту молочних продуктів існують на ринках країн Близького Сходу та Північної Африки, але це потребує відповідної адаптації товарного асортименту молокопереробних підприємств через дослідження споживчих уподобань на відповідних ринках. Зростає імпорт молочних продуктів і зі сторони Китаю, що є особливо привабливим для українських молокопереробних підприємств на фоні зменшення виробництва молока найбільших країн-виробників у світі - Австралії та Нової Зеландії.

Проте у 2016 р. українські молокоперобні підприємства поставили на експорт продукції на 9\% менше, ніж у 2015 р. Зменшення відбулося в усіх групах молочних продуктів, крім масла, поставки якого виросли на $2,6 \%$.
До найбільших імпортерів ураїнських молокопродуктів належать такі країни, як Казахстан (16\%), Молдова (13\%), Туркменістан (8\%), Грузія (7\%), Пакистан (5\%), Вірменія, В’єтнам та Бангладеш (по 4\%), Китай і Сгипет (по 3\%). У 2016 р. передбачається, що експортні поставки молокопродуктів залишаться на рівні 2016 р. і становитимуть 450 тис. т.

Значною загрозою для функціонування молокопереробних підприємств є зростання прихильності населення до молочних продуктів, закуплених на ринках. Це призвело до того, що протягом останніх дев'яти років споживання молочних продуктів промислового виробництва в Україні зменшилося на 25\%, а «базарних» за аналогічний період зросло на 79\%, що у грошовому вираженні еквівалентно 20 млрд грн на рік. Потенційними конкурентами молокопереробних під- 
приємств є молочні кооперативи, одним з яких $є$ «Перший молочний кооператив», заснований у вересні 2015 р. 3 метою виробництва молока екстра гатунку, об'єднавши 27 ферм, які щомісячно реалізують 8500 т молока. Одночасно він проводить переговори з молокоперобними підприємствами з урахуванням інтерсів усіх ферм. Для утримання існуючої та збільшення частки ринку велику увагу молокоперобні підприємства повинні приділяти заходам паблісіті та стимулювання збуту, об'єднавши свої дії в межах реалізації заходів у сфері просування. Мова йде про пропагування споживання саме продуктів промислового виробництва через проведення їхньої дегустації у навчальних закладах, організацію проведення екскурсій для школярів та студентів на молокопереробні підприємства 3 поясненням переваг їх продукції порівняно 3 «базарною», проведення незалежної оцінки якості такої продукції та аналогічної приватних і фермерських господарств 3 поширенням отриманих результатів у пресі, на радіо- та телебаченні, в Інтернеті.

\section{Висновки}

Отже, в сучасних умовах посилення конкуренції на ринку молока та молокопродуктів України за рахунок приватних виробників і фермерських господарств молокопереробні підприємства повинні стимулювати попит на продукти промислового виробництва шляхом їх активного просування на ринок. Це передбачає використання ними заходів стимулювання збуту та паблісіті. Зростання загроз на вітчизняному ринку молока, зменшення пропозиції молока на світовому ринку з боку головних країн-експортерів відкриває нові можливості для активізації діяльності вітчизняних молокопереробних підприємств у сфері експорту. Останній напрям пов'язаний із дослідженням споживчих уподобань щодо молокопродуктів на ринках інших країн насамперед із використанням вторинної маркетингової інформації.

Перспективи подальших досліджень пов'язані 3 дослідженням споживчих уподобань в Україні стосовно молока та молокопродуктів в умовах зменшення доходів споживачів. Це передбачає збирання первинної маркетингової інформації шляхом опитування споживачів. Значні можливості у цьому напрямі відкриває використання мережі Інтернет.

\section{Бібліографічні посилання}

Kubrak, N.R. Krykavs'kyy, Ye.V., Kosar, N.S. (2013). Potentsial elastychnosti $\mathrm{u}$ formuvanni konkurentospromozhnosti promyslovykh pidpryyemstv: Monohrafiya. L'viv: Vydavnytstvo L'vivs'koyi politekhniky (in Ukrainian).

Petrynyak, U.Ya. (2011). Udoskonalennya marketynhovoyi diyal'nosti molokopererobnykh pidpryyemstv: Avtoreferat dysertatsiyi na zdobuttya naukovoho stupenya kandydata ekonomichnykh nauk zi spetsial'nosti 08.00.04 - ekonomika ta upravlinnya pidpryyemstvamy (ekonomika sil's'koho hospodarstva i APK). Bila Tserkva, 20 (in Ukrainian).
Poperechnyy, S.I., Kudla, T.Yu. (2016). Aktual'ni problemy marketynhovoyi diyal'nosti sil's'kohospodars'kykh pidpryyemstv. Naukovyy visnyk LNUVMBT imeni S.Z. Gzhyts'koho «Ekonomichni nauky». 18, 2(69), 118-122 (in Ukrainian).

Moloko ta molokoprodukty: osnovni pidsumky 2016 roku (2016). [Elektronnyy resurs]. - Rezhym dostupu: http://agravery.com/uk/posts/show/moloko-tamolokoprodukti-osnovni-pidsumki-2016-roku Ukrainian).

TOP-10 naybil'shykh vyrobnykiv molochnoyi produktsiyi v Ukrayini [Elektronnyy resurs]. - Rezhym dostupu: http://agravery.com/uk/posts/show/top-10-najbilsihvirobnikiv-molocnoi-produkcii-v-ukraini (in Ukrainian).

Tsikhanovs'ka, V.M. (2016). Stan ta perspektyvy rozvytku rynku moloka ta molochnykh produktiv Ukrayiny [Elektronnyy resurs]. Ekonomika. Upravlinnya. Innovatsiyi. 1(16). - Rezhym dostupu: :irbis-nbuv.gov.ua/cgi-

bin/irbis_nbuv/cgiirbis_64.exe?C21CO (in Ukrainian).

Yakist' moloka zdanoho na pererobku pokrashchuyet'sya [Elektronnyy resurs]. - Rezhym dostupu: http://agravery.com/uk/posts/show/akist-molokazdanogo-na-pererobku-pokrasuetsa-avm (in Ukrainian).

Minahropolityky prohnozuye skorochennya vyrobnytstva moloka na 2,88\% [Elektronnyy resurs]. - Rezhym dostupu: http://agravery.com/uk/posts/show/ minagropolitiki-prognozue-skorocenna-virobnictvamoloka-na-288 (in Ukrainian).

Import molokoproduktiv v Ukrayinu u 2017 zroste na $30 \%$ [Elektronnyy resurs]. - Rezhym dostupu: http://agravery.com/uk/posts/show/importmolokoproduktiv-v-ukrainu-u-2017-zroste-na-30 (in Ukrainian).

Nimechchyna stala naybil'shym importerom moloka $\mathrm{v}$ Ukrayinu [Elektronnyy resurs]. - Rezhym dostupu: http://agravery.com/uk/posts/show/nimeccina-stalanajbilsim-importerom-moloka-v-ukrainu (in Ukrainian).

Molochna heohrafiya abo komu nasha «molochka» do smaku [Elektronnyy resurs]. - Rezhym dostupu: gravery.com/uk/posts/show/molocna-geografia-abokomu-nasa-molocka-do-smaku (in Ukrainian).

Reytynh eksporteriv molochnoyi produktsiyi u 2016 rotsi [Elektronnyy resurs]. - Rezhym dostupu: http://agravery.com/uk/posts/show/rejting-eksporterivmolocnoi-produkcii-u-2016-roci (in Ukrainian).

Import molokoproduktiv v Ukrayinu u 2017 zroste na $30 \%$ [Elektronnyy resurs]. - Rezhym dostupu: http://agravery.com/uk/posts/show/importmolokoproduktiv-v-ukrainu-u-2017-zroste-na-30 (in Ukrainian).

Rynok moloka: pidsumky 2016 roku ta prohnozy na nastupnyy rik [Elektronnyy resurs]. - Rezhym dostupu: http://a7d.com.ua/novini/31794-rinokmoloka-pdsumki-2016-roku-ta-prognozi-nanastupniy-rk.html. (in Ukrainian).

«Pershyy molochnyy kooperatyv» zoseredyvsya na vyrobnytstvi moloka ekstra gatunku [Elektronnyy resurs]. - Rezhym dostupu: http://agravery.com/uk/ posts/show/persij-molocnij-kooperativ-zoseredivsana-virobnictvi-moloka-ekstra-gatunku (in Ukrainian). Стаття надійшла до редакиії 15.02.2017 